Creative Commons User License: CC BY-NC-ND

Abstracted by: EBSCOhost, Electronic Journals Service (EJS),

Google Scholar, Journal Seek, Scientific Commons,

Food and Agricultural Organization (FAO), CABI and Scopus

http://eoi.citefactor.org/10.11226/v24i2
Journal of Agricultural Extension

Vol. 24 (2) April, 2020

ISSN(e): 24086851; ISSN(Print); 1119944X

http://journal.aesonnigeria.org

http://www.ajol.info/index.php/jae

Email: editorinchief@aesonnigeria.org

\title{
Perceptions of the Relationship between Cultural Biases and Farmer-Herder Conflicts in Taraba State, Nigeria
}

https://dx.doi.org/10.4314/jae.v24i2.11

Mahmood, Hamid U.

Department of Agricultural Economics and Extension

Taraba State University, Jalingo. Email: mahmoodmambilla@yahoo.com, +2348137055315

\section{Azuaga, Chia I.}

Department of Vocational and Technical Education, Taraba State University, Jalingo. Email: azuachia2010@yahoo.com

\section{Abstract}

This study examined the relationship between cultural biases and farmer-herder conflicts in Taraba State, Nigeria. The population was made up of 973 respondents comprising the households of selected farmers and herders in Taraba State. The sample size of210 was selected using purposive sampling procedure. The instrument for data collection was an 18-item questionnaire. One hundred and ninety-five (195) copies of the questionnaire were successfully retrieved and analysed. Mean and standard deviation was used to summarise the data. Findings indicated that cultural barriers which spots nomads as strangers in farming communities is among some aspects of cultural biases that promote farmer-herder conflicts in Taraba State. Government should come up with policies that will reduce the vegetative impact of cultural preferences and barriers.

Keywords: Cultural biases, farmer-herder conflicts, socio-economic activities

\section{Introduction}

Crop production and livestock rearing are major fields of agricultural production in subsaharan Africa and the world over. Okwor (2016) asserts that pastoralism and crop farming are two important sources of livelihood and subsistence in Nigeria and the world as a whole as human beings rely on meat, milk, grain, other crops and leather. These two agricultural sectors have also been the source of concern and worries as a result of conflicts in almost all parts of Africa. Farmer-herder conflict is a common conflict that occurs between sedentary crop farmers and pastoralists livestock farmers. According to Ndubuisi (2018) factors that promotes these conflicts includes unauthorised encroachment into farm lands causing damage to crops and fallow lands. Other causes include continual destruction of crops by Fulani cattle, competition over the use of natural resources, especially land and water, ethnic cleavages, misunderstandings arising from personal animosities between the two groups and the lack of institutions in managing farmer-pastoralist conflicts. Similarly, Adisa in Ningxin (2018) reported 
Creative Commons User License: CC BY-NC-ND

Abstracted by: EBSCOhost, Electronic Journals Service (EJS),

Google Scholar, Journal Seek, Scientific Commons,

Food and Agricultural Organization (FAO), CABI and Scopus

http://eoi.citefactor.org/10.11226/v24i2
Journal of Agricultural Extension

Vol. 24 (2) April, 2020

ISSN(e): 24086851; ISSN(Print); 1119944X

http://journal.aesonnigeria.org

http://www.ajol.info/index.php/jae

Email: editorinchief@aesonnigeria.org

environmental factors and the scarcity of resources as the causes of these conflicts between farmers and herdsmen.

Furthermore, Akerjiir (2018) stresses that it is worthy to note that in the past, crop farmers and the pastoralist groups had a cordial and stable relationship that enables the people to work side by side for decades. This interdependent relationship on each other is evident as both groups depend on each other for survival, and it formed the benchmark for exchange and which brought about even development. The crop farmers and the pastoralist have a long heritage and economic relationship, though there were sources of disagreement existing between both groups that were resolved by both groups peacefully (Akerjiir, 2018)

In recent times, several studies have highlighted the major causes of these conflicts to include desertification, resource control especially land, water and pasture. Kwaja and Ademola-Adelehin (2018) opine that environmental degradation, social manipulation of ethno-religious biases, and technological advances have altered relationships that were historically interdependent and mutually beneficial. Similarly, several efforts have been made by governments at different levels, non-governmental organisations and individuals to address these causes. This has however not yielded the desired results hence the need for further studies on the non-material causes of these conflicts. Bukari (2017) stresses that farmer-herder relations are basically situated within the milieu of cultural neighbourhood, characterized by cross-cutting ties of co-existence, and, at the same time, by ethnic/cultural differences and conflict. These relations are also shaped by social networks and social ties built over time. These social networks and social ties that have been established over time are altered due to cultural biases.

Cultural bias in the opinion of Abuwala (2019) is a form of ethnocentrism in which people from a particular ethnic background judge the outside world through a worldview based on their own cultural standards. These biases occur when people of a given culture assume that their social conventions are universal. They feel that people who do not follow those conventions are outcasts. They refuse to acknowledge ethnic diversity, which leads to social disharmony. This social disharmony is further fuelled by hate speeches and other hateful conducts.

Cultural bias according to Haddad and Purtilo (2019) involves a tendency to interpret a word or action according to culturally derived meaning assigned to it. Cultural bias can be described as discriminative. There is a lack of group integration of social values, beliefs, and rules of conduct. Cultural bias introduces one group's accepted behaviour as valued and distinguishable from another lesser valued societal group. Cultural bias has been found to be a factor in determining where particular persons live, and what they have available as educational and health care opportunities. Cultural bias is the phenomenon of interpreting and judging phenomena by standards inherent to one's own 
Creative Commons User License: CC BY-NC-ND

Abstracted by: EBSCOhost, Electronic Journals Service (EJS),

Google Scholar, Journal Seek, Scientific Commons,

Food and Agricultural Organization (FAO), CABI and Scopus

http://eoi.citefactor.org/10.11226/v24i2
Journal of Agricultural Extension

Vol. 24 (2) April, 2020

ISSN(e): 24086851; ISSN(Print); 1119944X

http://journal.aesonnigeria.org

http://www.ajol.info/index.php/jae

Email: editorinchief@aesonnigeria.org

culture. A cultural bias is a tendency to interpret a word or action according to culturally derived meaning assigned to it. Cultural biases are naturally occurring environmental observations about the world (Aschheim \& Singer, 2015).

Culture is a broad concept used in describing both the visible and invisible, material and non-material components of human existence. According to Jibo in Shija (2018) culture is made up of the ideas, beliefs, customs or traditions, means and methods of survival, provision of security and protection, individual and collective relationships, institutional organisation and administration, general and dissemination of knowledge, maintenance of health and treatment of sicknesses, production and distribution of foods and goods, clothing and housing, reproduction and socialisation as well as rewards of punishments. These cultural dimensions must be accepted and shared by a group of people within a given society or locality.

In recent times, rather than relying on the material aspects of farmer-herder conflicts, efforts are made to identify more causes of such conflicts. Bukari (2017) reiterated that reducing farmer-herder conflicts to just structural factors and to environmental/climate change and resource scarcity, from the perspectives of both the environmental scarcity/security school and that of farmer-herder perceptions, is far more complex than assumed. Rather, a plethora of political, historical, social and ecological factors drives violent conflict escalation. In addition, violent conflict escalation develops through a process, social networks and a constellation of diverse actors who play significant roles in their escalation. Similarly, Akerjiir (2018) opined that it is still insufficient to accept that factors stated above are enough to escalate the conflicts between herders and farmers because all these factors associated with the increase in conflicts are not new. Without a doubt, there are more complexities associated with farmers-herders conflict in Nigeria.

Cultural biases are demonstrated by the feeling of superiority of one's culture and cultural activities over that of others. For instance, Ajibo, Onuoha, Obi-Keguna, Okafor and Oluwole (2018) reported a Fula proverb which says: "Cattle surpass everything, it's even more important than father and mother" "if cattle die, then fulbe dies". Based on this proverb, the Fulani hold their cattle in high esteem than other humans. Such dispositions could continue to promote farmer-herder conflicts. It is worthy to note that the antagonistic perceptions and beliefs among farmers and herdsmen could compound conflict situation, especially due to failing institutions and fierce competition for resources.

Similarly, some crop farmers equally hold negative perception about the herders and their livelihood pattern. Bukari (2017) reported that in Ghana, the perception of local peoples, local authorities, the media and the general populace is that farmer-herder relations are basically conflictual. For instance, little is known about how cooperation and social networks among the two are built and hardly anything about how they are 
Creative Commons User License: CC BY-NC-ND

Abstracted by: EBSCOhost, Electronic Journals Service (EJS),

Google Scholar, Journal Seek, Scientific Commons,

Food and Agricultural Organization (FAO), CABI and Scopus

http://eoi.citefactor.org/10.11226/v24i2
Journal of Agricultural Extension

Vol. 24 (2) April, 2020

ISSN(e): 24086851; ISSN(Print); 1119944X

http://journal.aesonnigeria.org

http://www.ajol.info/index.php/jae

Email: editorinchief@aesonnigeria.org

maintained. The over-emphasis on conflicts, especially violent conflicts often presents a gloomy situation by exaggerating it and portraying the Fulani in a particularly negative light, as perpetrators of these violent conflicts, which makes them the target of hatred in communities.

It is no doubt that the incessant farmer-herder conflicts are promoted by individuals and groups who either directly or indirectly benefit from these conflicts. Corroborating the above assertion, Ajibo et al., (2018) stresses that ethnic jingoists and politicians have been benefitting in these strives and without doubt has succeeded in creating a divide between the farmers and pastoralist, especially in communities that are less educated. Cultural diversities should not be seen as a means of division but should rather be used to harness people's resources, talents, ideas, and labour for the common good.

The purpose of the study was to examine the relationship between cultural biases, and farmer-herder conflicts in Taraba State, Nigeria. Specifically, this study sought to:

- $\quad$ examine the aspects of cultural biases that promotes farmer-herder conflicts; and

- identify the consequences of farmer-herder conflicts on economic activities of the respondents.

\section{Methodology}

The study was conducted in Taraba State which lies on longitude $10^{\circ} 58^{\prime}$ and $50.52^{\prime}$. It is bounded in the west by Nasarawa State and Benue State, northwest by Plateau State, north by Bauchi State and Gombe State, northeast by Adamawa State, south and east by Cameroon. The state has sixteen (16) local government areas and one special development area. The state lies largely within the tropical zone and has a vegetation of low forest in the southern part and grassland in the northern part. The major occupation of the people of the State is farming and livestock rearing. The state has in recent times experience series of farmer-herder conflicts necessitating this study.

The population for the study was 973 households comprised of farmers and herders who were registered under the Anchor Borrowers Programme as at November, 2016 in Taraba State (Taraba State Ministry of Agriculture, Jalingo, 2016). The sample size for the study was 210 respondents made up of 105 farmers and 105 herders. Purposive sampling procedure was used for the study. In the first stage, three (3) local government areas of Lau, Gassol and Donga were purposively selected. These are local government areas that have either experienced or are currently experiencing the farmer-herder conflicts. In the second stage, thirty-five farmers and thirty-five herdsmen from each of the local government areas were seletced.

The instrument used for data collection was an 18 Likert-type item questionnaire. The questionnaire had four-point response options of strongly agree (4), agree (3), disagree (2) and strongly disagree (1). A total of 210 copies of the instrument were distributed to 
Creative Commons User License: CC BY-NC-ND

Abstracted by: EBSCOhost, Electronic Journals Service (EJS),

Google Scholar, Journal Seek, Scientific Commons,

Food and Agricultural Organization (FAO), CABI and Scopus

http://eoi.citefactor.org/10.11226/v24i2
Journal of Agricultural Extension

Vol. 24 (2) April, 2020

ISSN(e): 24086851; ISSN(Print); 1119944X

http://journal.aesonnigeria.org

http://www.ajol.info/index.php/jae

Email: editorinchief@aesonnigeria.org

the respondents and 195 copies were retrieved. Weighted mean and standard deviation were used to summarise the data. A mean cut-off point of 2.50 and above was considered as agree while a mean of less than 2.50 was considered as disagree.

\section{Results and Discussion}

\section{Cultural Biases that Promote Farmer-Herder Conflicts}

Table 1 indicates that issues that prompt cultural biases were: preference of one's culture over the others culture $(\bar{x}=3.61)$, feeling of superiority of one's culture and cultural activities over that of others $(\bar{x}=3.60)$. The findings agree with the submission of Haddad and Purtilo (2019) that cultural bias involves a tendency to interpret a word or action according to culturally derived meaning assigned to it. Furthermore, some of the issues include: Fulani holds their cattle in high esteem than crops $(\bar{x}=3.57)$. The findings agree with a Fula proverb which says according to Ajibo et al., (2018) that "cattle surpass everything, it's even more important than father and mother" "if cattle die, then fulbe dies". Similarly, crop farmers hold their crops in high esteem than livestock $(\bar{x}=3.06)$, antagonistic perceptions and beliefs among farmers and herdsmen $(\bar{x}=2.54)$. This is in line with Abuwala (2019) that cultural bias is a form of ethnocentrism in which people from a particular ethnic background judge the outside world through a worldview based on their own cultural standards.

Furthermore, the antagonistic perceptions and beliefs among farmers and herdsmen could compound conflict situation, especially due to failing institutions and fierce competition for resources. Also, negative perception about herders and their livelihood pattern by crop farmers $(\bar{x}=2.63)$. This is in line with the finding of Bukari (2017) that in Ghana, the perception of local peoples, local authorities, the media and the general populace is that farmer-herder relations are basically conflictual. The over-emphasis on conflicts, especially violent conflicts often presents a gloomy situation by exaggerating it and portraying the Fulani in a particularly negative light, as perpetrators of these violent conflicts, which makes them the target of hatred in communities. Preference of one's religious beliefs over others $(\bar{x}=3.03)$, discrimination on the bases of food and other cultural ingredients $(\bar{x}=3.01)$. Also, cultural barriers which spots nomads as strangers in farming communities $(\bar{x}=2.51)$. 
Creative Commons User License: CC BY-NC-ND

Abstracted by: EBSCOhost, Electronic Journals Service (EJS),

Google Scholar, Journal Seek, Scientific Commons,

Food and Agricultural Organization (FAO), CABI and Scopus

http://eoi.citefactor.org/10.11226/v24i2
Journal of Agricultural Extension

Vol. 24 (2) April, 2020

ISSN(e): 24086851; ISSN(Print); 1119944X

http://journal.aesonnigeria.org

http://www.ajol.info/index.php/jae

Email: editorinchief@aesonnigeria.org

\begin{tabular}{|c|c|c|}
\hline Item & $\bar{x}$ & SD \\
\hline Preference of one's culture over another & 3.61 & .66 \\
\hline $\begin{array}{l}\text { The feeling of superiority of one's culture and cultural activities } \\
\text { over that of others }\end{array}$ & 3.60 & .69 \\
\hline Fulani holds their cattle in high esteem than crops & 3.57 & .60 \\
\hline Crop farmers hold their crops in high esteem than livestock & 3.06 & .85 \\
\hline $\begin{array}{l}\text { Antagonistic perceptions and beliefs among farmers and } \\
\text { herdsmen }\end{array}$ & 2.54 & .95 \\
\hline $\begin{array}{l}\text { Negative perception about herders and their livelihood pattern } \\
\text { by crop farmers }\end{array}$ & 2.63 & 1.03 \\
\hline Preference of one's religious beliefs over others & 3.03 & .91 \\
\hline $\begin{array}{l}\text { Discrimination on the bases of food and other cultural } \\
\text { ingredients }\end{array}$ & 3.01 & 1.04 \\
\hline $\begin{array}{l}\text { Cultural barriers which spot nomads as strangers in farming } \\
\text { communities }\end{array}$ & 2.51 & .72 \\
\hline
\end{tabular}

\section{Consequences of Farmer-Herder Conflicts on Economic Activities}

Table 2 indicates that consequences of farmer-herder conflicts on socio-economic activities were: reduced economic productivity $(\bar{x}=2.60)$, reduction in crop yields $(\bar{x}=$ $3.51)$, loss of products in storage $(\bar{x}=2.59)$, loss of cattle $(\bar{x}=3.79)$, reduction in the productivity of cattle $(\bar{x}=3.11)$. This is in line with the findings of Okwor $(2016)$ that the constant clashes between farmers and herdsmen have threatened the security of the state, reduced its economic productivity, and deepened food crisis. Further consequences include creation of vicious cycle of poverty in affected communities $(\bar{x}=$ 2.96), increase in the prices of food commodities $(\bar{x}=3.29)$ and reduction in income/savings of both farmers and herders $(\bar{x}=3.31)$. The findings agree with Ningxin (2018) that the Fulani-farmer conflict has a direct impact on people's lives and livelihoods as it causes high poverty rate and competition in addition to the creation of circles of extreme poverty and hunger, loss of lives and properties $(\bar{x}=3.65)$. This finding is in consonance with that of Gambari et al., in Ajibo et al., (2018) that due to farmers and herdsmen conflicts in Nigeria, thousands of people have been killed, communities have been destroyed and so many farmers and herdsmen have lost their lives and property in an extended orgy of killings and destruction that is not only continuously destroying livelihoods but also affecting national cohesion. 
Creative Commons User License: CC BY-NC-ND

Abstracted by: EBSCOhost, Electronic Journals Service (EJS),

Google Scholar, Journal Seek, Scientific Commons,

Food and Agricultural Organization (FAO), CABI and Scopus

http://eoi.citefactor.org/10.11226/v24i2
Journal of Agricultural Extension

Vol. 24 (2) April, 2020

ISSN(e): 24086851; ISSN(Print); 1119944X

http://journal.aesonnigeria.org

http://www.ajol.info/index.php/jae

Email: editorinchief@aesonnigeria.org

\begin{tabular}{lcc}
\hline Table 2: Consequences of farmer-herder conflicts on socio-economic activities \\
\hline Item & $\bar{x}$ & SD \\
\hline Reduced economic productivity & 2.60 & .81 \\
Reduction in crop yields & 3.51 & .42 \\
Loss of products in storage & 2.59 & .75 \\
Loss of cattle & 3.79 & .69 \\
Reduction in the productivity of cattle & 3.11 & .65 \\
Creation of vicious cycle of poverty in affected communities & 2.96 & .54 \\
Increase in the prices of food commodities & 3.29 & .83 \\
Reduction in income/savings of both farmers and herders & 3.31 & .80 \\
Loss of lives and properties & 3.65 & .79 \\
\hline
\end{tabular}

\section{Conclusion and Recommendations}

Cultural biases play a crucial role in promoting farmer-herder conflicts. These conflicts have serious implications on the economic activities and livelihood of both farmers and herdsmen. Positive aspects of cultural diversities should be emphasized by government and non-governmental organizations. Also, government should put in place sustainable peace building mechanisms to ensure lasting peace between farmers and herders.

\section{References}

Abuwala, A. (2019). What is Cultural Bias? Retrieved from https://www.worldatlas.com/articles/what-does-cultural-bias-mean.html

Ajibo, H.T.; Onuoha, E.C.; Obi-Keguna, C.N.; Okafor, A.E. and Oluwole, I. O. (2018). Dynamics of farmers and herdsmen conflict in Nigeria: The implication to social work policy intervention. International Journal of Humanities and Social Science, 8(7), 157-163

Akerjiir, A.S. (2018). Increasing farmer-herder conflict in Nigeria: An assessment of the clashes between the fulani herdsmen and indigenous farmers in Ukpabi-Nimbo community Enugu State. Master of Art dissertation, Wageningen University and Research, The Netherlands. $91 \mathrm{pp}$

Aschheim, K.W. and Singer, B.A. (2015). Fundamentals of esthetics and smile analysis. Retrieved from https://www.sciencedirect.com/topics/medicine-and-dentistry/culturalbias.

Bukari, K.N. (2017). Farmer-herder relations in Ghana: interplay of environmental change, conflict, cooperation and social networks. Doctoral Dissertation, Georg-August University of Göttingen. 320pp

Haddad, A. And Purtilo, R. (2019). Respect in a diverse society. In: Health professional and patient interaction (9 ${ }^{\text {th }}$ Edition). Retrieved from www.sciencedirect.com/topics/medicineand-dentistry/cultural-bias 
Creative Commons User License: CC BY-NC-ND

Abstracted by: EBSCOhost, Electronic Journals Service (EJS),

Google Scholar, Journal Seek, Scientific Commons,

Food and Agricultural Organization (FAO), CABI and Scopus

http://eoi.citefactor.org/10.11226/v24i2
Journal of Agricultural Extension

Vol. 24 (2) April, 2020

ISSN(e): 24086851; ISSN(Print); 1119944X

http://journal.aesonnigeria.org

http://www.ajol.info/index.php/jae

Email: editorinchief@aesonnigeria.org

Kwaja, C.M.A. and Ademola-Adelehin, B.I. (2018). Responses to conflicts between farmers and herders in the middle-belt of Nigeria: Mapping past efforts and opportunities for violence prevention. $14 \mathrm{pp}$

Ndubuisi, C.I. (2018). A critical analysis of conflicts between herdsmen and farmers in Nigeria: causes and socio-religious and political effects on national development. HTS Teologiese Studies/Theological Studies, 74(1), 1-6

Ningxin, L. (2018). Nigeria's Fulani herdsmen-farmers conflict and peace building. Global Journal of Agricultural Research, 6(5), 1-15

Okwor, D. (2016). The political economy of the conflict between the farmers and fulani herdsmen in the contemporary era of climate change in Nigeria. Unpublished Master of Arts Thesis, Institute of Social Studies, the Hague, Netherlands

Shija, T. (2018). Tiv cultural heritage and the idea of development in contemporary Nigerian society. IOSR Journal of Humanities And Social Science, 23(7), 1- 8

Taraba State Ministry of Agriculture, Jalingo (2016). Farmers' full list of Anchor Borrowers Programme as at November, 2016. 